Elif Kaya $^{1}$

Eralp Bektaş ${ }^{2}$

Mete Feridun ${ }^{3}$
UDK 336.761:330.35>(560)

336.71:330.35>(560)

Preliminary paper

Prethodno priopćenje

\title{
STOCK MARKET AND BANKING SECTOR DEVELOPMENT IN TURKEY: DO THEY HAVE THE SAME IMPACT ON ECONOMIC GROWTH?
}

\begin{abstract}
This article investigates the impact of financial stock market development and banking sector development on economic growth in the case of Turkey using Johansen cointegration and Granger causality tests for the period between 01:1988 and 12:2004. The results suggest that banking sector development has positive impact on economic growth and vice versa. Hence, the results lend support to both demand following and supply leading hypotheses for banking sector development and economic growth relationship. However, the results fail to yield the same conclusion for the stock market-economic growth relationship.
\end{abstract}

Key words: Granger-causality, banking sector, stock market

JEL classification: F31, F37

\section{INTRODUCTION}

As discussed in Feridun et al. (2009), the liberalization of the Turkish economy which began with the implementation of an IMF-prompted structural adjustment program in 1980, led to the inauguration of the Istanbul Stock Exchange in 1986. The same period witnessed a marked improvement in the Turkish capital markets in terms of the legislative framework and the institutions. This paved the way to the liberalization of capital account in 1989, through which the Turkish financial markets began to attract inflows of hot money.

Since then, economists and practitioners have long debated over the effects of the Turkish financial liberalization on the economy. The removal of restrictions on international capital transactions has generally been welcome as a growth opportunity in the broad literature (see Feridun et al 2009). However, in the case of Turkey, financial liberalization has also been blamed for rendering the economy vulnerable to speculative attacks (see, for instance, Feridun 2008, 2009, 2011 and Katircioglu and Feridun, 2010).

\footnotetext{
${ }^{1}$ Treasury Department,Credit West Bank Lefkosa, Mersin 10 Turkey

2 Department of Banking and Finance, Faculty of Business and Economics Eastern Mediterranean University, Gazi Magosa, Mersin 10 Turkey, E-mail: eralp.bektas@emu.edu.tr

3

3 Department of Banking and Finance, Faculty of Business and Economics Eastern Mediterranean University , Gazi Magosa, Mersin 10 Turkey, E-mail: mete.feridun@emu.edu.tr
} 
From a theoretical standpoint, different views exist regarding finance-growth nexus. Schumpeter (1911) argues that well performing banking system can contribute to economic growth by technological innovations which may occur as a result of efficient allocation of funds. In contrast, Robinson (1952) states that financial development is a result of improvements in economic performance.

Patrick (1966) suggests that there exists a bi-directional theoretical relationship between financial development and economic growth, namely demand-following and supply-leading relationships. In the former case the creation of financial intermediaries, their assets, liabilities and financial services is the result of demand for them. On the other hand, in the latter case, the creation of financial institutions, their financial assets and liabilities and financial services precedes the demand for them (Patrick, 1966).

In theory, stock market development may affect economic growth through various channels. For instance, stock markets may reduce risks for an investor who is reluctant to relinquish control of their savings for a long time. Liquidity enables investors to sell quickly and have easy access to their equities and by issuing equities enables firms to have a permanent access to capital. Also, long term and profitable projects will be easily financed, which, in turn, produce improvements in capital allocation and increase in economic growth.

Against this theoretical backdrop, this article aims to make a contribution to the existing literature by investigating the impact of financial development, as proxied by stock market development and banking sector development, on economic growth in Turkey using Johansen cointegration and Granger causality tests.

The rest of the study is structured as follows. Section II reviews the literature and Section III introduces the data and methodology. Section IV presents the empirical results, and Section V points out the conclusions that emerge from the study.

\section{LITERATURE REVIEW}

There exists a plethora of studies on the nexus between financial development and economic growth. Following work of Bagehot (1873), Schumpeter (1911), Gurley and Shaw (1955), Goldsmith (1969) and McKinnon (1973) researchers employed different econometric methodologies and data sets to investigate finance-growth relationship between different countries. As Levine (2003) explains, a growing body of empirical research, using different statistical procedures and data sets, produces remarkably consistent results showing that countries with developed financial systems tend to grow faster.

Studies such as Beck et al (2000), Levine et al (2000), King and Levine (1993), Bekaert et al (2003), Bhattacharya and Sivasubramanian (2003), Kar and Pentecost (2000), Cetintas and Barisik (2003), Levine and Zervos (1996), Calderon and Liu (2003), Khan and Senhadji (2003), Mazur and Alexander (2001), Christopoulos and Tsionas (2004), Soukhakian (2007a, 2007b), Ergungor (2008), and Jalil et al (2010) have generally found evidence that financial system development causes economic growth.

On the other hand, some studies have yielded contradicting findings. For instance, Demirguc-Kunt and Levine (1996) found empirical evidence that as countries become developed, their financial structure improves. Similarly, Boulila and Trabelsi (2002) found 
that economic growth causes financial development. In addition, Rousseau and Vuthipadadorn (2005) obtained evidence of a bi-idirectional causal relationship between the two variables, whereas Chang (2002) found no evidence of a relationship between economic growth and financial development. The present study aims at making a contribution to the literature by studying the impact of stock market and banking sector development on economic growth in Turkey.

\section{DATA AND METHODOLOGY}

The data used in the present study is monthly, spans the period between 01:1988 and 12:2004, and have been obtained from the Central Bank of Turkish Republic of Turkey's web site. Economic growth is measured by real GDP per capita. The indicator of stock market development is value traded as the ratio of the total value of domestic shares traded on the stock market to GDP (VLTR). Value traded is the total value of domestic shares traded on the stock market and measures the trading volume of the stock markets as a share of GDP. It reflects the degree of liquidity that stock markets provide to economy (Beck et al, 2000). As the banking system development indicator, the ratio of liquid liabilities (currency plus demand and interest bearing liabilities of banks and non-bank financial intermediaries) of the financial system to GDP (FINDP) is used. Liquid liabilities are a typical measure of financial depth and are widely used as a measure of financial intermediation (see Beck et al, 2000). All variables are transformed into logarithmic returns.

In order to investigate the causal relationship between financial system development and economic growth, Johansen cointegration tests are applied. This methodology is extensively discussed in the literature and, therefore, has not been discussed here to preserve space. To implement the Johansen test we first examine the time series properties of the said variables. If variables are found to be integrated of same order, cointegration relationship can be investigated among them. If cointegration exists Granger causality is tested based on ECM, otherwise, simple Granger causality test is applied which is based on first difference bi-variate VAR between same order integrated variables.

Error correction mechanism ${ }^{4}$ has been widely used in economics and carries the advantages of identifying the sources of Granger causation or disequilibrium adjustment. The simple idea behind ECM is that a proportion of the disequilibrium from one period is corrected in the next period (Engle and Granger, 1987).

The model can be expressed as follows:

$$
\begin{aligned}
& \Delta \ln Y_{t}=\mu+\sum_{i=1}^{m} a_{i} \Delta \ln Y_{t-i}+\sum_{i=1}^{m} b_{i} \Delta \ln X_{t-i}+\beta_{i} E C T_{t-1}+u_{t} \\
& \Delta \ln X_{t}=\mu+\sum_{i=1}^{m} c_{i} \Delta \ln X_{t-i}+\sum_{i=1}^{m} d_{i} \Delta \ln Y_{t-i}+\eta_{i} E C T_{t-1}+u_{t}
\end{aligned}
$$

Where $Y$ denotes Real GDP per capita and $X$ denotes financial system development indicators which are found to have cointegration relationship with Real GDP per capita. $a_{i}, b_{i}$, $c_{i}$ and $d_{i}$ represents short run coefficients and $\beta_{\mathrm{i}}$ and $\eta_{\mathrm{i}}$ represents speed of adjustment

\footnotetext{
${ }^{4}$ For early versions see Sargan (1964) and Philips (1957)
} 
coefficients. $E C T_{t-1}$ is error correction term and contains $r$ co-integrating terms, reflecting the long-run equilibrium relationship among variables. Also, measures the proportion by which the long term imbalance in dependent variable is corrected in each short run period. $\Delta$ indicates first difference operator.

If $\beta_{\mathrm{i}}$ and $\eta_{\mathrm{i}}$ are found as statistically significant, this means that deviation exists from long-run equilibrium. In order to correct this deviation, it is expected that values of $\beta_{i}$ and $\eta_{i}$ will be negative number which means variables are moving towards equilibrium.

In ECM, sources of causation can be exposed by applying three different tests. The first one is a joint test applied to the sum of the lags of each explanatory variable in turn using $F$ test which also represents existence of short run causality. Second one is a t-test on the lagged EC term which is in fact a weak exogeneity ${ }^{5}$ test and represents the existence of long-run causality. The last one is the joint test applied to the sum of each explanatory variable and the lagged EC term which is a strong exogeneity ${ }^{6}$ test (Charemza and Deadman, 1997).

The joint null hypothesis for equations 1 and 2 is that, $X$ does not Granger causes $Y$ and $Y$ does not Granger causes $X$, in other words there is no Granger causality between $X$ and $Y,\left(b_{i}, d_{i}=0\right) . \mathrm{H}_{\mathrm{o}}$ is rejected if sum of the lags of each explanatory variables and EC term is found statistically significant, using $F$-test and t-test respectively.

\footnotetext{
${ }^{5}$ A variable $X_{t}$ is said to be weakly exogenous for estimating a set of parameters $\lambda$, if inference on $\lambda$ conditional on $X_{t}$ involves no loss of information. (Maddala, 1992, page 392)

${ }^{6}$ If $X_{t}$ is weakly exogenous and $X_{t}$ is not preceded by any of the endogenous variables in the system, $X_{t}$ is defined to be strongly exogenous. (Maddala, 1992, page 393)
} 


\section{EMPIRICAL RESULTS}

In order to investigate the stationarity properties of the variables, Augmented Dickey Fuller (ADF) and Zivot-Andrews (ZA) have been used. As can be seen from tables 1 and 2, all variables are integrated of order one, $I(1)$.

Table 1. ADF Test for Unit Root

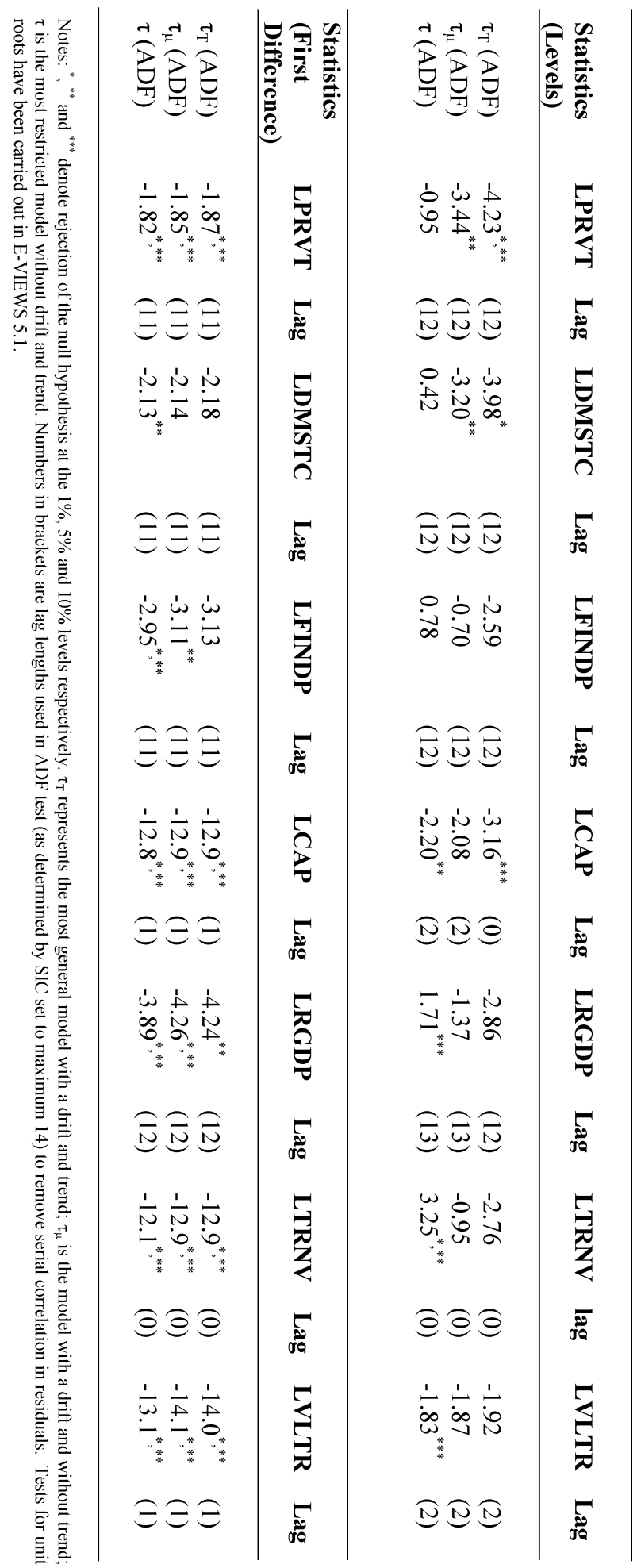


Table 2. Zivot and Andrew unit root test for one break

\begin{tabular}{|c|c|c|c|c|c|}
\hline Variable & Model & $\boldsymbol{k}$ & Break & $\boldsymbol{t}\left(\lambda_{\text {inf }}\right)$ & Inference \\
\hline LPRVT & A & 13 & $\begin{array}{c}2001 \\
\text { month } 3\end{array}$ & $-6.21^{*, * * * * *}$ & Statioanry \\
\hline LDMSTC & A & 13 & $\begin{array}{c}2001 \\
\text { month } 3\end{array}$ & $-5.45^{*, * * * * * *}$ & Statioanry \\
\hline LCAP & B & 12 & $\begin{array}{c}1999 \\
\text { month } 12\end{array}$ & $-4,78^{* *, * * *}$ & Stationary \\
\hline LVLTR & B & 6 & $\begin{array}{c}1989 \\
\text { month } 12\end{array}$ & -3.19 & $\begin{array}{c}\text { Non- } \\
\text { statioanry }\end{array}$ \\
\hline LFINDP & C & 12 & $\begin{array}{c}1989 \\
\text { month 4 }\end{array}$ & -3.35 & $\begin{array}{c}\text { Non- } \\
\text { statioanry }\end{array}$ \\
\hline LRGDP & C & 12 & $\begin{array}{c}2000 \\
\text { month } 12\end{array}$ & -5.07 & $\begin{array}{c}\text { Non- } \\
\text { statioanry }\end{array}$ \\
\hline LTRNV & C & 12 & $\begin{array}{c}2002 \\
\text { month 5 }\end{array}$ & $-5.44^{* *, * * *}$ & Statioanry \\
\hline
\end{tabular}

Notes: i) Model specification (i.e which model, A, B, or C is appropriate) is determined by first running each data series on Model C, with the possibility of both a slope and a level break. Model $\mathrm{C}$ is chosen if both dummy variables are significant. If only the slope dummy variable is significant, Model B is estimated. If only the level dummy is significant, Model A is estimated. ii) ${ }^{*},{ }^{* *}$ and ${ }^{* * *}$ denote rejection of the null hypothesis at the $1 \%, 5 \%$ and $10 \%$ levels respectively. Critical values are taken from Zivot and Andrew (1992). The 1\%, 5\% and $10 \%$ critical values are $-5.34,-4.80$ and -4.58 ,respectively, for model A. For model B, -4.93, -4.42 and -4.11 ,respectively, and $-5.57,-5.08$ and 4.82, respectively, for model C.

The results of Johansen cointegration test are reported in Table 3. Cheung and Lai (1993) suggest that the Trace test shows more robustness to both skewness and excess kurtosis in the residuals than maximum eigenvalue test. Hence, trace test statistics are used in the present study to determine the existence of co-integrating relationships.

Table 3. Cointegrtion tests based on the Johansen (1988) approach

\begin{tabular}{|l|l|l|l|l|l|}
\hline Variables & Hypothesis & $\begin{array}{l}\text { Trace } \\
\text { Statistics }\end{array}$ & $\begin{array}{l}\% \\
\text { critical } \\
\text { value }\end{array}$ & $\begin{array}{l}\text { \%1 } \\
\text { critical } \\
\text { value }\end{array}$ & Inference \\
\hline $\begin{array}{l}\text { LRGDP- } \\
\text { LFINDP }\end{array}$ & $\begin{array}{l}\mathrm{H}_{\mathrm{o}}: \mathrm{r}=0 \\
\mathrm{H}_{\mathrm{a}}: \mathrm{r}=1\end{array}$ & $\begin{array}{l}19.726 \\
0.522\end{array}$ & $\begin{array}{l}15.41 \\
3.76\end{array}$ & $\begin{array}{l}20.04 \\
6.65\end{array}$ & $\begin{array}{l}\text { Co- } \\
\text { integrated } \\
\text { at \%5 }\end{array}$ \\
\hline $\begin{array}{l}\text { LRGDP- } \\
\text { LVLTR }\end{array}$ & $\begin{array}{l}\mathrm{H}_{\mathrm{o}}: \mathrm{r}=0 \\
\mathrm{H}_{\mathrm{a}}: \mathrm{r}=1\end{array}$ & $\begin{array}{l}15.62 \\
2.62\end{array}$ & $\begin{array}{l}15.41 \\
3.76\end{array}$ & $\begin{array}{l}20.04 \\
6.65\end{array}$ & $\begin{array}{l}\text { Co- } \\
\text { integrated } \\
\text { at \%5 }\end{array}$ \\
\hline
\end{tabular}

Notes: $r$ denotes the number of cointegrating vectors, SCI was used to select the number of lags required in cointegrating test, Critical values are taken from Osterwald-Lenum (1992) 
Table 4. Granger causality tests based on Error Correction Models (ECM)

\begin{tabular}{|c|c|c|c|c|c|c|c|c|c|c|c|c|}
\hline $\begin{array}{l}\text { Null } \\
\text { Hypothesis }\end{array}$ & $\begin{array}{l}\text { F- } \\
\text { stat }\end{array}$ & $\begin{array}{l}t- \\
\text { sta } \\
\text { t }\end{array}$ & $\begin{array}{l}F- \\
\text { stat }\end{array}$ & $\begin{array}{l}t- \\
\text { stat }\end{array}$ & $\begin{array}{l}F- \\
\text { stat }\end{array}$ & $\begin{array}{l}t- \\
\text { stat }\end{array}$ & $\begin{array}{l}F- \\
\text { stat }\end{array}$ & $\begin{array}{l}t- \\
\text { stat }\end{array}$ & $\begin{array}{l}F- \\
\text { stat }\end{array}$ & $\begin{array}{l}t- \\
\text { stat }\end{array}$ & $\begin{array}{l}F- \\
\text { stat }\end{array}$ & $\begin{array}{l}t- \\
\text { sta } \\
\text { t }\end{array}$ \\
\hline & Lag & 6 & Lag & 12 & Lag & 18 & Lag & 24 & Lag & 30 & Lag & 36 \\
\hline FINDP & 20.3 & 2.6 & 37. & 2.68 & 24.0 & 2.30 & 20.6 & 2.49 & 14.8 & 2.37 & $11.3^{*}$ & 2.0 \\
\hline $\begin{array}{l}\text { does not } \\
\text { Granger } \\
\text { cause } \\
\text { RGDP }\end{array}$ & $8^{*, * *}$ & $6^{* *}$ & $17_{* *}^{*}$ & $*$, & $5^{*, * *}$ & & $4^{*, * *}$ & & $6^{*, * *}$ & & & $3^{* *}$ \\
\hline RGDP does & 13.8 & 2.7 & 49. & 3.28 & 31.5 & 3.29 & 26.8 & 2.97 & 19.3 & 1.80 & $15.6^{*}$ & 2.4 \\
\hline $\begin{array}{l}\text { not Granger } \\
\text { cause } \\
\text { FINDP }\end{array}$ & $8^{*, * *}$ & $3^{* *}$ & $46_{* *}^{*}$ & & $2^{*, * *}$ & & $7^{*, * *}$ & & $4^{*, * *}$ & & & $4_{*}^{*, *}$ \\
\hline VLTR does & 17.1 & 1.2 & 28. & 1.87 & 19.0 & 0.40 & 19.2 & 0.77 & 14.7 & 2.79 & $10.3^{*}$ & 0.4 \\
\hline $\begin{array}{l}\text { not Granger } \\
\text { cause } \\
\text { RGDP }\end{array}$ & $3^{*, * *}$ & 2 & $78^{*}$ & & $1^{*, * *}$ & & $1^{*, * *}$ & & $* * *$ & & & 0 \\
\hline $\begin{array}{l}\text { RGDP does } \\
\text { not Granger } \\
\text { cause } \\
\text { VLTR }\end{array}$ & $\underset{*, * *}{3.86}$ & $\begin{array}{l}2.8 \\
1^{* *}\end{array}$ & $\begin{array}{l}2.7 \\
1_{*}^{*, *}\end{array}$ & ${ }_{*}^{3.68}$ & $\begin{array}{c}37.1 \\
7^{*}\end{array}$ & $\underset{*, * *}{4.26}$ & 1.70 & $\underset{*, * *}{2.73}$ & 1.74 & 0.51 & $1.95^{*}$ & $\begin{array}{l}3.4 \\
8^{*, *}\end{array}$ \\
\hline
\end{tabular}

Johansen test results suggest that there exists one cointegration vector between LRGDPLFINDP and LRGDP-LVLTR. In other words, although series are non-stationary at their levels; they share common stochastic trends in the long-run.

The next step is to determine of the direction of Granger causality between cointegrated variables. In order to capture both long run and short run effects, Granger causality relationship is investigated using 6 month intervals till 36 month lag. While Table 4 reports the results of $F$-statistics and $t$-statistics of error correction term, Table 5 reports the coefficients of error correction terms for Granger causality test based on ECM. The coefficient of error correction term is found statistically significant and is negative, which shows that the variables in the system have a tendency to restore equilibrium.

For the case of financial depth and Real GDP per capita, both in the long-run and shortrun, bi-directional Granger causality exists between variables. It can be said that while financial depth is a leading factor for RGDP per capita, at the same time RGDP per capita is leading factor for financial depth. In other words, improvements in real economy will produce consistent increases in the size of the banks and non-bank financial intermediaries. On the other hand, as financial sector develops and increases the amount of financial services and when size of sector increases this will create improvements in economic growth. Therefore, policymakers should take in to consideration of both sectors while they are designing policies for financial system and real economy.

On the other hand, when we evaluate the results for value traded and Real GDP per capita we see that there is no consistency in results and the direction of causality changes with 
different lags. The reason behind instability in results may be weak correlation between stock market and real economy when value traded ratio is considered as an indicator for stock market development.

In general, for value traded and real GDP per capita, Granger causality relationship shows that, while in the short run bi-directional Granger causality exists, in the long run Granger causality is running from real GDP per capita to value traded ratio. Hence, it can be said that, in the short run, increased stock market liquidity creates more demand to investments, which in turn improves real GPD per capita.

If we compare the Granger causality test results of financial depth- real GDP per capita and value traded-real GDP per capita we see that Granger causality relationship between value traded ratio and RGDP per capita is not stronger as in relationship between financial depth and real GDP per capita.

\section{CONCLUSION}

This article has investigated the impact of financial development, as proxied by stock market development and banking sector development, on economic growth in Turkey using Johansen cointegration and Granger causality tests.

The results suggest that banking sector development has positive impact on economic growth and vice versa. Hence, the results lend support to both demand following and supply leading hypotheses for banking sector development and economic growth relationship. However, the results fail to yield the same conclusion for the stock market-economic growth relationship.

Thus, the results suggest that bank-based financial systems are more effective to promote long term growth than capital-market based one in the case of Turkey. This implies that, in order to promote economic growth, the policy-makers should increase the size of the financial sector and vice versa.

\section{REFERENCES}

Bagehot, W. (1873), Lombard Street, A Descrtiption of the Money Market. Homewood, IL: Richard D. Irwin, (1962 Edition)

Beck, T.; Levine, R. and Loayza, N. (2000), "Finance and the Sources of Growth.”, Journal of Financial Economics, 58(1-2), pp. 261-300

Bekaert, G.; Herve, C. R. and Lundblad, C. T. (2003) "Does Financial Liberalization Spur Growth?”, Journal of Financial Economics, 77, 3-55

Bhattacharya, P. C. and Sivasubramanian M. N., (2003), "Financial Development and Economic Growth in India; 1970-71 to 1998-1998”, Applied Financial Economics, 13, pp. 925-929

Boulile, G. and Trabelsi, M., (2002), Unpublished Working Paper.

Calderon, C. and Liu, L., (2003), “The Direction of Casuality between Financial Development and Economic Growth.” Journal of Development Economics, 72, 321-334

Cetintas, H. and Barısık, S., (2003), "Turkiye'de Bankalar, Sermaye Piyasası ve Ekonomik Buyume: Koentegrasyon ve Nedensellik Analizi”,Iktisat-Isletme ve Finans Dergisi, Sayı: 25-26 
Chang, T., (2002), "Financial Development and Economic Growth in Mainland China: a note on testing demand-following or supply leading hypothesis”, Applied Economics Letters, 9, pp. 869-873

Christopoulos, D. K. and Tsionas, E. G. (2004). Financial development and economic growth: Evidence from panel unit root and cointegration tests. Journal of Development Economics, 73, 55-74.

Demirguç-Kunt. A. and Levine, R., (1996), "Stock Markets, Corporate Finance and Economic Growth: An Overview.” World Bank Economic Review, vol. 10, no. 2, pp. 223-39

Ergungor, O. E. (2008). Financial system structure and economic growth: Structure matters. International Review of Economics \& Finance, 17(2), 292-305.

Feridun, M. (2008) Currency Crises in Emerging Markets: The Case of Post-Liberalization Turkey, The Developing Economies, 46(4), 386-927

Feridun, M. (2009) Determinants of Exchange Market Pressure in Turkey: An Econometric Investigation, Emerging Markets Finance and Trade, 45(2), 65-81

Feridun, M. (2011) Liability dollarization, exchange market pressure and fear of floating: Empirical evidence for Turkey, Applied Economics, 44(8), 1041-1056

Feridun, M., Sawhney, B. and Jalil, A. (2009) Stock Market and Investment in an Emerging Economy: The Case of Turkey, Ekonomska Istrazivanja-Economic Research, 22(4), 17-29

Goldsmith, R. W. (1969), Financial Structure and Development, New Haven, CT: Yale University Press.

Gurley, John G. and Shaw, Edward S. (1955), "Financial Aspects of Economic Development.”, American Economic Review, 45(4), pp. 515-38

Jalil, A., Feridun, M. and Ma, Y. (2010) "Finance-Growth Nexus in China Revisited: New Evidence from Principal Components and ARDL Bounds Tests”, International Review of Economics and Finance, 19, 189-195

Kar, M. and E. J. Pentecost, (2000) "Financial Development and Economic Growth in Turkey: Further Evidence on the Causality Issue” Loughborough University, Economic Research Paper, No. 00/27

Katircioglu, S. and Feridun, M. (2010) Do macroeconomic fundamentals affect exchange market pressure? Evidence from Bounds Testing Approach for Turkey, Applied Economics Letters, 18(3), 1466-4291

Khan, Mohsin S. and Senhadji, Abdelhck S, (2003), "Financial Development and Economic Growth: A Review and New Evidence.” Journal of African Economies, vol. 12, pp. 89-110

King, Robert G. and Levine, R. (1993), "Financial Intermediation and Economic Development," in Colin Mayer and Xavier Vives, eds., Capital Markets and Financial Intermediation. London: Centre for Economic Policy Research, pp. 156-89

Levine, R. and Zervos, S., (1996), “Stock Market Development and Long-Run Growth”, World Bank Economic Review, vol. 10, no. 2, pp. 323-39

Levine, R., (2003), “More on Finance and Growth: More Finance, More Growth?”, Unpublished Working Paper, The Federal Reserve Bank of St. Louis

Levine, R, Loayza, N. and Beck, T. (2000) "Financial Intermediation and Growth: Casuality and Causes.” Journal of Monetary Economics, 46(1), pp. 31-77

Maddala, G. S., 1992, "Introduction to Econometrics”, Second Edition, Wiley, New York

Mazur, E. A. and Alexander, R. J. (2001). "Financial Sector Development and Economic Growth in New Zealand.” Applied Economics Letters, 8, pp. 545-549

McKinnon, R. I. (1973), Money and Capital in Economic Development, Washington, DC: Brookings Institutions

Patrick H. T. (1966). "Financial Development and Economic Growth in Underdeveloped Countries.” Economic Development and Cultural Change, 14, 174-189 
Philips, A. W. (1957) "Stabilization Policy and the Time Forms of Lagged Responses" Economic Journal, 67, 265-277

Robinson, J. (1952), The Generalization of the General Theory, in the Rate of Interest and Other Essays, Macmillan, London

Rousseau, P. L. and Vuthipadadorn, D. (2005)., "Financial, investment, and growth:

Time series evidence from 10 Asian economies", Journal of Macroeconomics, 2787-106

Sargan, J. D. (1964), "Wages and Prices in the United Kingdom: A Study in Econometric Methodology” Econometric Analyses for National Economuc Planning, ed. by P.E. Hart, G. Mills and J.N. Whittaker. London: Butterworths

Schumpeter, J. A. (1911). The Theory of Economic Development. Cambridge, Mass: Harvard University Press.

Soukhakian, N. (2007a) Financial Development and Economic Growth in Iran: Evidence from Co-Integration and Causality Tests, International Journal of Economic Perspectives, (1)2, 56-63

Soukhakian, B. (2007b) Financial Development, Trade Openness and Economic Growth in Japan: Evidence from Granger Causality Tests, International Journal of Economic Perspectives, (1)3, 117-123

\title{
RAZVOJ BURZE I BANKARSKOG SEKTORA U TURSKOJ: IMAJU LI JEDNAK UTJECAJ NA EKONOMSKI RAST?
}

\begin{abstract}
SAŽETAK
Rad istražuje utjecaj razvoja financijskog tržišta dionica i bankarskog sektora na ekonomski rast u Turskoj koristeći Johansenov kointegracijski i Grangerov test kauzalnosti za period od siječnja 1988. do prosinca 2004. Rezultati ukazuju na to da razvoj bankarskog sektora ima pozitivni utjecaj na ekonomski rast i suprotno. Stoga, rezultati potkrepljuju obje hipoteze (demand following i supply leading) odnosa razvoja bankarskog sektora i ekonomskog rasta. Ipak, rezultati ne upućuju na jednak rezultat kad je u pitanju odnos burze i ekonomskog rasta.
\end{abstract}

Ključne riječi: Granger-kauzalnost, bankarski sektor, burza

JEL klasifikacija: F31, F37 